\title{
ANÁLISE DINÂMICA DO CAPITAL DE GIRO O MODELO FLEURIET
}

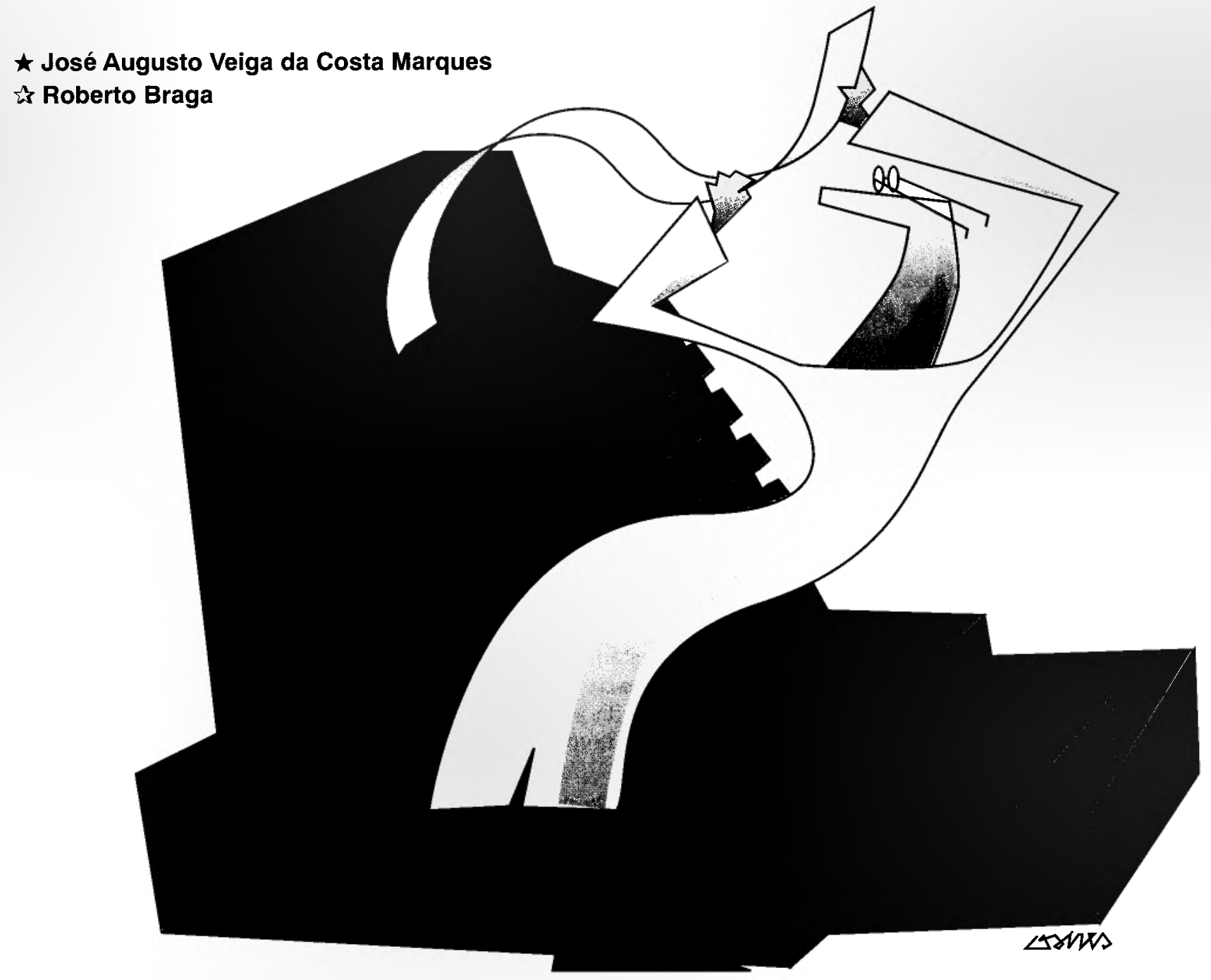

\section{PALAVRAS-CHAVE:}

Liquidez, solvência, investimento operacional em giro, capital circulante líquido, lucro bruto operacional, fluxo de caixa operacional, modelo Fleuriet, capital de giro, desempenho operacional, rentabilidade.

\section{KEY WORDS:}

Liquidity, solvency, current operational investment, net working capital, operational gross profit, operational cash flow, Fleuriet model, working capital, operational performance, rentability.

\section{$\star$ Professor Assistente do Departamento de Contabilidade da FEA/UFRJ e Doutorando em Administraçáo Contábil e Financeira na EAESP/FGV.}

\section{Pesquisador e Protessor Doutor da FEA/USP.}




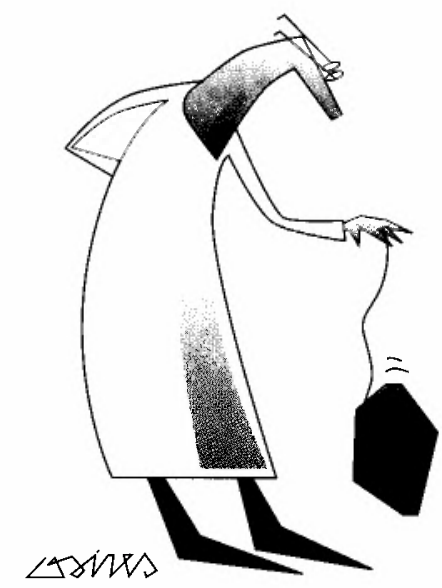

\section{O modelo Fleuriet para avaliação da liquidez e estrutura de financiamento é um importante instrumento de análise e/ou controle para tomada de decisões financeiras.}

\author{
The Fleuriet model for liquidity and financing \\ structure evaluation is a relevant instrument of \\ analysis and/or internal control in making financial \\ decisions.
}

1. FLEURIET, Michel, KEHDY, R., BLANC, G. A Dinâmica financeira das empresas brasileiras. 2. ed. Belo Horizonte: Fundação Dom Cabral, 1980.

2. BRASIL, H. V., BRASIL, H. G. Gestão financeira das empresas: um modelo dinâmico. 2. ed. Quality Mark Editora: Fundação Dom Cabral, 1993.

3. SILVA, José P. Análise financeira das empresas. 2. ed. São Paulo: Atlas, 1993.

4. BRAGA, Roberto. Análise avançada do capital de giro. São Paulo: FEA/USP, n. 3, set. 1991 (Cadernos de Estudo FIPECAFI).
E m face às turbulências surgidas no ambiente econômico do qual as empresas participam, em grande parte motivadas por alterações no mercado como, por exemplo, maior nível de competitividade, inflação e variações sazonais nos preços dos insumos -, começaram a aparecer pesquisas com ênfase em avaliações dinâmicas do comportamento dos elementos patrimoniais de curto prazo, em contraposição às análises financeiras convencionais com base em relações quase sempre estáticas.

Em seus estudos sobre gestão financeira de empresas, Fleuriet ${ }^{1}$ descreveu um modelo de análise dinâmica da situação financeira das organizações, favorecido pela experiência francesa nessa área de conhecimento. Em seguida outros autores, tais como Brasil e Brasil ${ }^{2}$, Silva ${ }^{3}$ e Braga ${ }^{4}$, aprimoraram determinados aspectos do modelo original, inclusive no sentido de aplicá-lo a casos reais, bem como buscando divulgá-lo de uma maneira articulada.

Este artigo procura desenvolver o modelo citado, explicar sua relevância no contexto da análise da liquidez e solvência à luz de seus aprimoramentos incorporados, e integrá-lo à análise de quocientes tradicionais como instrumento útil para a avaliação financeira de negócios.

Foi utilizada uma amostra de seis companhias abertas do ramo industrial, classificadas entre as maiores por faturamento, que empregaram o modelo para a avaliação de seus níveis de liquidez e solvência em 1993.

\section{PROCEDIMENTOS METODOLÓGICOS}

A pesquisa realiza uma análise descritiva do modelo Fleuriet de avaliação da posição financeira de negócios, incorporando seus principais aprimoramentos surgidos nesses últimos anos.

Além disso, aplica a metodologia desenvolvida a uma amostra de seis companhias nacionais de capital aberto, do ramo de produtos agrícolas/alimentos, de maneira a verificar o comportamento da liquidez dessas empresas no exercício de 1993.

A composição da amostra adotou critério randômico, ao passo que os dados (demonstraçōes financeiras não-padronizadas, elaboradas com base no método da correção integral) foram conseguidos junto aos arquivos da Comissão de Valores Mobiliários (CVM). Esses relatórios foram reorganizados para um formato apropriado à análise, e deles, extraídas informações (valores e relações) relevantes.

\section{REORGANIZAÇÃO DOS DEMONSTRATIVOS FINANCEIROS}

Para compreender o modelo, há necessidade de reorganizar as contas integrantes do balanço patrimonial e de outros relatórios contábeis para um formato direcionado à análise. Nesse sentido, os principais conceitos discutidos por Fleuriet partiram dessa nova composição.

\section{Balanço patrimonial}

O balanço convencional, elaborado em conformidade com as normas estabele- 
cidas pela Lei $n^{0} 6.404 / 76$, relaciona as contas que compõem as fontes e destinações de recursos como mostra o quadro 1.

Em linhas gerais, os elementos do ativo circulante caracterizam-se por constituir bens ou direitos realizáveis financeiramente, em condiçóes normais, em prazo inferior a um ano. O passivo circulante, por sua vez, expressa obrigações compromelidas $\mathrm{cm}$ igual periodo. Os demais ativos c passivos, c o patrimônio líquido, representam itens de natureza de prazo mais longo.

\section{Quadro 1 \\ Grupos integrantes do balanço patrimonial \\ Aplicaçöes de recursos Origens de recursos $\begin{array}{cc}\text { Ativo Circulante } & \text { Passivo Circulante } \\ \mathrm{AC} & \mathrm{PC}\end{array}$ \\ Realizavel a Longo Prazo Exigivel a Longo Prazo ARLP PELP \\ Ativo Permanente AP \\ Resultado de Exercicios Futuros REF \\ Patrimônio Liquido Pl}

Dadas as suas proporçoes, os grupos circulantes abrangem itens de natureza operacional - que tendem a se renovar constantemente em função da continuidade das operacōes rotineiras - ou nàooperacional - que surgem de decisões negociadas e não-espontâneas, sem ligação direta com as operações da firma. Desse modo, o ativo circulante pode ser desmembrado em ativo circulante cíclico (ACC) e ativo circulante financeiro (ACF). No primeiro segmento, encontram-se as contas associadas à atividade operacional, como, por exemplo, duplicatas a receber provenientes das vendas, provisão para créditos de liquidação duvidosa, adiantamentos a fornecedores, adiantamentos a empregados, estoques de matérias-primas, produtos em processo ou acabados, peças para reparos de ativos fixos, material administrativo, provisão para ajuste a valor de mercado, impostos sobre valor agregado a compensar (ICMS - Imposto sobre Circulação de Mercadorias) e IPI (Imposto sobre Produtos Industrializados), e seguros e aluguéis antecipados. Já no ACF distribuem-se as contas fundo fixo de cai$x a$, bancos, conta movimento ou vincula- da (às vezes pode incluir depósitos judiciais), aplicaçôes financeiras de curtíssimo prazo, títulos e valores mobiliários (prazo inferior a um ano), imposto de renda restituível e créditos contra empresas coligadas (empréstimos, dividendos ou faturas).

No lado do passivo circulante, por seu turno, identificam-sc o passivo circulante cíclico (PCC) e o passivo circulante oncroso (PCO). O primeiro abrange as contas decorrentes das atividades operacionais espontâneas, como duplicatas a pagar oriundas da compra de matérias-primas e/ ou mercadorias, impostos sobre valor agregado a recolher, adiantamentos de clientes, salários e encargos sociais a pagar, e participações de empregados a pagar. No segundo grupo, ficariam as contas resultantes, usualmente de negociaçōes específicas, como empréstimos e financiamentos bancários de curto prazo, imposto de renda e contribuição social a recolher, dividendos a pagar a acionistas, dividas frente a coligadas, participaçōes estatutárias, adiantamentos de câmbio e duplicatas descontadas.

O item representativo do desconto de duplicatas foi considerado pelo autor integrante do PCO por constituir uma origem financeira de recursos para a empresa, ao passo que imposto de renda, obrigações com coligadas e dividendos foram incluídos por se tratarem de contas erráticas. $O$ primeiro argumento poderia ainda ser aplicado a adiantamentos de câmbio, e o segundo às participaçóes no lucro.

Os outros grupos patrimoniais do ativo e passivo foram agrupados como ativos nào-circulantes (ANC, representa a soma do ARLP (Realizável a Longo Prazo) ao AP(Ativo Permanente) e passivos nãocirculantes (PNC, que engloba PELP (Exigível a Longo Prazo), RFF (Resultado

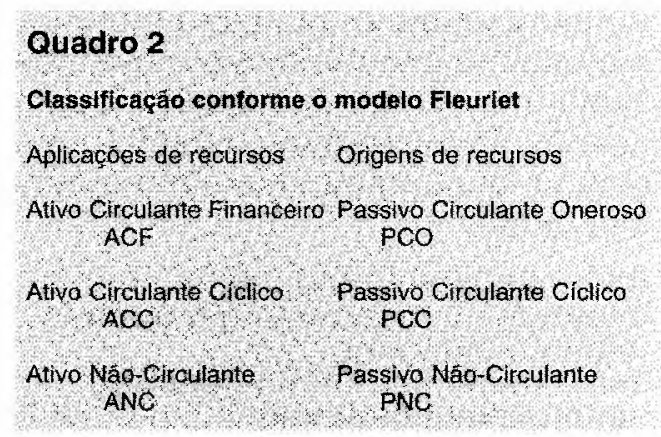


de Exercícios Futuros) e PL (Patrimônio Líquido). No primeiro ficariam os itens geradores de produto, enquanto no outro, as fontes normais de recursos de longo prazo disponíveis. O quadro 2 expõe a nova composição do demonstrativo.

Todavia, podem ocorrer dificuldades no tocante à classificação de determinadas comtas. Por exemplo, as contas a receber em prazo inferior a um ano oriundas da alienaçâo de ativo imobilizado ou investimento permanente, integrantes do $A C$, náo se enquadrariam no $\mathrm{ACC}$ (Ativo Circulante Cíclico) e no ACF. Os dividendos a pagar e o imposto de renda a recolher, que compoem o PC (Passivel Circulante), também não se identificariam

\section{Quadro 3}

Demonstração de resultado de empresa Industrìal

Receitas líquidas de vendas

(+) Receitas da prestacáo de serviços

(t) Outras receitas de natureza operacional

(t) Variação de estoques de produtos acabados

(+) Variação de estoques de produtos em processo

(-) Produçäo

(-) Compras de matérias-primas

(-) Variaçáo de estoques de matérias-primas

(-) Despesas com vendas (inclusive lCMS)

(-) Despesas gerais e administrativas

$\Leftrightarrow$ Consumo intermediário

(-) Despesas mão-de-obra (inclusive honorários de diretores)

(-) Despesas com impostos (exclusive os de renda e ICMS)

(=) Lucro bruto operacional antes das despesas financeiras

(-) Despesas financeiras líquidas

(-) Despesas não-operacionais líquidas

(-) Imposto de renda

(-) Dividendos

$\Leftrightarrow$ Autofinanciamento

de maneira direta ao PCC e ao PCO. Ainda assim, por serem suas participações relativas pouco expressivas em condições normais, entendeu-se ser mais adequada a sua inclusão nos segmentos cíclicos e não-cíclicos, respectivamente.

A nova composição para as contas do passivo possui alguma identidade com aquela sugerida por Heath ${ }^{5}$. As fontes negociadas propostas por Heath incluiriam o passivo circulante oneroso de Fleuriet, subtraído da parcela correspondente aos títulos e duplicatas descontados, mais o total dos financiamentos e debêntures pagáveis a longo prazo, e o imposto de renda diferido.

Fontes negociadas $=$ PCO - titułos

5. HEATH, L. C. Is working capital really working? Journal of Accountancy, New York, Aug. 1980
As fontes espontâneas, por seu lado, englobariam o passivo circulante cíclico e o passivo exigivel a longo prazo näo-financeiro - como adiantamentos de clientes por produção de bens ou prestação de serviços por empreitada. Participariam também dessas fontes as obrigaçóes frente a coligadas derivadas de antecipaçóes de compras.

\section{Demonstração de resultado}

Do mesmo modo, a demonstração de resultado requer modificaçoes quanto à sua estrutura clássica. No caso de uma empresa industrial (ver quadro 3), do total líquido das receitas operacionais da empresa são deduzidas as variaçoes nos estoques de produtos acabados e em processo - sem o cômputo da depreciação, amortização ou exaustão - de modo a atingir o montante da produção. Desse valor deduzem-se as compras e variaçoes nas matérias-primas, bem como as despesas com vendas, e administrativas, daí resultando o montante do consumo intermediário. Outra vez, subtraem-se deste os gastos incorridos com empregados c diretores, e também com impostos faturados. O saldo remanescente equivale ao lucro bruto operacional (LBO).

O LBO constitui a fonte geradora de recursos destinada à remuneração dos financiadores, fisco e acionislas. Ao excluir do $L B O$ os encargos financeiros líquidos (de curlo ou longo prazo), despesas nãooperacionais líquidas (inclusive os resultados de equivalência patrimonial), imposto de renda, e dividendos propostos, encontra-se o montante do autofinanciamento.

Em qualquer empresa industrial, parte das despesas incorridas com depreciação, amortização e exaustão, identificáveis ou atribuíveis aos estoques, integra o custo dos produtos vendidos, ao passo que outra parte compóe seu valor remanescente, relatado no balanço final. Determinadas despesas dessa natureza podem ainda estar contidas nas despesas com vendas, $\mathrm{e}$ gerais e administrativas. Contudo, o modelo exclui esses encargos do cálculo do LBO, de forma a cvitar inconsistências pela possibilidade de adoção de práticas de apropriação diferenciadas entre as empresas, ou dentro dela mesma. O mesmo raciocínio poderia ser usado para outros provisionamentos, usualmente de menor expressão. 
Essa exclusảo lambém poderia ser realizada deduzindo-se, do custo dos produtos vendidos, a parcela incorrida de depreciação, amortizaçāo e exaustão nele embutida.

No caso de uma empresa comercial, o LBO scria obtido de maneira bem mais simples, conforme evidencia o quadro 4. Aqueles encargos estariam contidos somente nas despesas com vendas, e gerais e administrativas.

\section{Quadro 4}

Demonstraçăo de resultado de empresa comercial

Receita operacional liquida

(-) Custo das mercadorias vendidas

(=) Lucro bruto

(-) Despesas com vendas, gerais e administrativas, de mão-de-obra, e com impostos (exceto imposto de renda e ICMS)

(=) Lucro bruto operacional antes das despesas financeiras

\section{Fluxo de caixa operacional e} autofinanciamento

Relativo ao terceiro relatório, o fluxo de caixa operacional (FCO) elaborado por Fleuriet representa uma medida financeira do montante do caixa gerado ou consumido pela atividade operacional do negócio num período específico, e pode ser calculado por meio de ajustes ao LBO das variaçóes nos ativos e passivos cíclicos de curto prazo ocorridas ao longo desse período (ver quadro 5 ).

O montante do autofinanciamento que expressa uma medida econômica do montante de recursos gerado pela firma que se destina ao financiamento de seu próprio crescimento - pode ser achado de duas maneiras distintas. Na primeira, excluindo do LBO as parcelas relativas às despesas financeiras e não-operacionais

\section{Quadro 5}

\section{Fluxo de caixa operacional}

Lucro bruto operacional

(-) Variaçāo nos itens do ativo circulante ciclico

(+) Variaçāo dos itens do passivo circulante cíclico

(=) Fluxo de caixa operacional

líquidas, o imposto de renda e a contribuição social, as participações estatutárias e os dividendos. Na outra forma, por meio da eliminação das despesas com depreciação, amortização c exaustão embutidas no resultado contábil (mediante sua soma), $\mathrm{c}$ exclusão do montante dos dividendos.

LBO antes das despesas financeiras

(-) Despesas financeiras líquidas, despesas não operacionais líquidas, imposto de renda e contribuição social, participaçōes no lucro, e dividendos

(=) Autofinanciamento

Lucro (ou prejuizo) líquido

(+) Despesas de depreciação, amortização e exaustão

(-) Dividendos

$\Leftrightarrow$ Autofinanciamento

\section{Formulação alternativa}

Alguma semelhança existe entre a demonstração de resultado construída pelo modelo Fleuriet e aquela outra preparada por Marques e Francisco Filho em seu estudo sobre o comportamento das margens de lucro do setor de autopeças (ver quadro 6).

Him outras palavras, o LBO aproximase do Lucro Operacional I (LOI) do mode-

\section{Quadro 6}

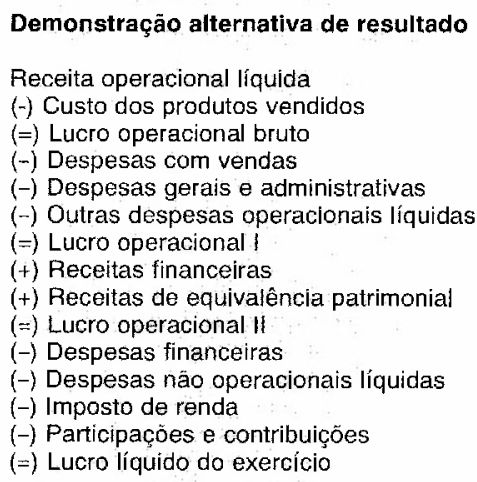

lo alternativo, o qual também significa uma medida financeira do desempenho operacional. O LOI exclui participaçōes e contribuiçoees sobre o lucro (participaçōes de empregados e administradores, por exemplo), e inclui os encargos de depreciação, amortização e exaustão incorridos, acontecendo o inverso para o cálculo do LBO - este pode abranger a participaçāo de empregados - ou seja:

LOI + participaçäo de empregados -

depreciação, amortização e exaustão = LBO

Outra analogia diz respeito à comparação entre o fluxo de caixa operacional descrito por Fleuriet e o caixa gerado das atividades operacionais recomendado pelo 
SFAS nº 95 na adoção do método indireto (ver quadro 7). Em princípio, os dois montantes tendem a coincidir, uma vez que $o$ LBO aparentemente se aproxima do capital de giro das operaçóes.

As variaçóes nos ativos e passivos operacionais citadas pelo SFAS $n^{-9} 95$ incluem também as das contas duplicatas descontadas, títulos e valores mobiliários, e créditos a receber de coligadas (pertencentes ao ativo), e imposto de renda a recolher, contribuição social, dividendos a pagar, e valores a pagar a coligadas (do passivo). Já as listadas por Fleuriet não as incluem, pois somente as contas de natureza cíclica seriam computadas nessas variações.

Por conscguinte, a eventual diferença de valor entre o LBO e o LOI seria compensada pelo cômputo de algumas daquelas contas no cálculo do LBO.

Essas constataçóes facilitam sobremaneira a utilização de uma medida operacional aproximada do desempenho das empresas para fins de análise financeira externa. Ao mesmo tempo, possibilitam o cálculo de um montante aproximado do fluxo de caixa operacional - ou seja,

\section{Quadro 7}

Fluxo operacional - Fleuriet e SFAS n ${ }^{\circ} 95$

Lucro contábil

(+) Depreciaçäo/amortizaçăo/exaustăo (+) Depreciação, amortização

(-) Dividendos

$\Leftrightarrow$ Autofinanciamento

(+) Despesas financeiras líquidas

(+) Despesas não-operacionais

(+) Imposto de renda

(+) Dividendos

() Lucro bruto operacional

(-) Variação no ACC

(t) Variação no $P C C$

$(t)$ Fluxo de caixa operacional

Nota: Os sinais ( + e -) promovem eliminaçóes de valores contidos no resultado contábil, à exceção dos dividendos e variaçōes, os quais nāo integram esse resultado.

6. 0 gasto total incorrido consta dos ajustes ao resultado contábil para cálculo do capital de giro gerado das operações, item que compõe a DOAR o caixa gerado e/ ou consumido pela atividade operacional, integrante da demonstraçâo de fluxos de caixa (DFC) -por meio de ajustes ao lucro bruto operacional das variaçóes ocorridas nos ativos e passivos cíclicos.

Pelo fato de a DFC ainda não haver sido solicitada para propósito de divulgação às companhias abertas não-financeiras, parece exeqüivel o emprego do FCO do modelo Fleuriet como um substituto do caixa gerado das operações, a principal atividade divulgada naquele relatório.

\section{$\mathrm{O}$ investimento operacional em giro}

Com base na classificação sugerida, Fleuriet relacionou alguns componentes relevantes a uma administração financeira adequada do empreendimento. O primeiro di $\angle$ respeito ao capital circulante líquido (CCL), ou capital de giro líquido, que pode ser obtido a partir dos grupos patrimoniais de curto prazo, ou de longo prazo, conforme segue.

$$
\begin{aligned}
& A C+A R L P+A P=P C+P E L P+R E F+P L \\
& C C L=(A C-P C)=(P E L P+R E F+P L-A R L P-A P)
\end{aligned}
$$

Em situaçôes usuais o CCL significa um valor positivo, ou seja, os recursos investidos no AC que ultrapassaram o total das fontes de financiamento de curto prazo (PC) foram financiados por itens de longo prazo (PNC). Em outras palavras, as origens de longo prazo suplantaram as necessidades de investimento de longo prazo, e foram aplicadas no capital de giro (AC). Pelo lado inverso, CCL negativo significa que fontes de recursos excedentes de curto prazo estão financiando elementos de longo prazo ou, do outro ponto de vista, as origens de longo prazo são insuficientes para financiar as aplicaçóes de recursos de longo prazo. Esta condição, se mantida por longo período, e dependendo da estrutura financeira da firma, pode repercutir na insolvência do empreendimento.

O comportamento do CCL pode ser melhor avaliado com base na decomposiçăo dos grupos circulantes em seus respectivos segmentos:

$$
C C L=(A C F+A C C)-(P C O+P C C)
$$

O segundo componente de análise consiste no investimento operacional em giro (1OG) - ou necessidade de capital de giro ${ }^{6}$. Seu montante seria conseguido pela diferença entre os elementos cíclicos. L .ogo:

$$
I O G=A C C-P C C
$$

Quando positivo, o IOG refere-se ao investimento líquido de curto prazo necessário, numa situação estática, à manutenção do atual nível da atividade operacional, que precisa ser financiado pelo 
PCO e/ ou pelo PNC. Esse elemento guarda proporcionalidade ao ciclo financeiro e ao volume de vendas praticados.

Por sua vez, o terceiro componente corresponde ao saldo de tesouraria (T), obtido por meio da diferença entre os elementos erráticos (não-ligados de forma direta às operaçóes usuais) do ativo e passivo de curto prazo.

$$
T=A C F-P C O
$$

$\mathrm{O} \mathrm{T}$ pode sinalizar o grau de adequaçāo da política financeira empregada pela administração. Quando positivo, indica disponibilidade de recursos para garantir a liquidez de curtíssimo prazo do empreendimento. Caso seja negativo, pode evidenciar dificuldades financeiras iminentes, em especial por ocasiāo da manutenção de saldos negativos sucessivos $\mathrm{e}$ crescentes. $\mathrm{O}$ acompanhamento da evolução do T no decorrer de exercícios sociais sucessivos, bem como das causas das eventuais alteraçōes de tendências percebidas, representa o cerne do modelo.

$O$ relacionamento entre os três conceitos pode ser visualizado pela simples diferença entre as equaçôes básicas de composição do $\mathrm{AC}$ e do $\mathrm{PC}$, ou seja:

$$
(-) \quad \begin{aligned}
& A C=A C C+A C F \\
& P C=P C+P C O \\
& \hline C C L=10 G+T
\end{aligned}
$$

A tabela 1 apresenta um balanço patrimonial convencional para uma série de anos, com os montantes expressos em moeda de mesma data (dados corrigidos para moeda de 31-12-1994). Com base no gráfico 1 nota-se que, embora a empresa tenha conseguido crescimento de seu ativo total ao longo dos seis anos, o CCL sempre positivo - não vislumbrou a mesma tendência após 1993, quando declinou em termos nominais. Por sua vez, o IOG sinalizou a mesma tendência do CCL, porém com defasagem de um período. O saldo de tesouraria foi negativo durante todo o período, o que indica a presença de fontes onerosas de curto prazo (PCO) financiando parte das necessidades de capital de giro. $\mathrm{O} T$ revelou sensível deterioração da posição financeira do empreendimento, muito embora tenha ensaiado uma reversão de tendência nos últimos três exer-

\begin{tabular}{|c|c|c|c|c|c|c|}
\hline \multicolumn{7}{|l|}{ alanço e indicadores } \\
\hline Código/grupo & 1987 & 1988 & 1989 & 1990 & 1991 & 1992 \\
\hline $\begin{array}{l}11 \text { Ativo Girculante (AC) } \\
111 \text { Disponfivel } \\
112 \text { Clientes } \\
113 \text { Duplicatas descontadas } \\
114 \text { Estoques } \\
115 \text { Despesas antecipadas } \\
12 \text { Realizaivel a Longo Prazo (ARLP) } \\
13 \text { Ativo Permanente (AP) } \\
131 \text { Investimento } \\
132 \text { Imobilizado } \\
133 \text { Diferido } \\
\text { Ativo total (AT) }\end{array}$ & $\begin{array}{r}26.500 \\
1.200 \\
15.000 \\
11.500\rangle \\
11.000 \\
800 \\
8.000 \\
35.800 \\
2.000 \\
32.000 \\
1.800 \\
70.300\end{array}$ & $\begin{array}{r}35.400 \\
2.000 \\
19.000 \\
(1.700) \\
15.000 \\
1.100 \\
9.000 \\
40.500 \\
3.000 \\
35.000 \\
2.500 \\
84.900\end{array}$ & $\begin{array}{r}45.500 \\
1.800 \\
26.000 \\
(2.600) \\
19.000 \\
1.300 \\
10.000 \\
47.900 \\
33000 \\
42.000 \\
2.900 \\
103.400\end{array}$ & $\begin{array}{r}54.100 \\
2.500 \\
35.000 \\
(2.900) \\
18.000 \\
1.500 \\
7.000 \\
50.100 \\
4.000 \\
43000 \\
3.100 \\
111.200\end{array}$ & $\begin{array}{r}51.700 \\
2.900 \\
28.000 \\
(3.100) \\
23.000 \\
900 \\
9.000 \\
51.000 \\
8.000 \\
40.000 \\
3.000 \\
111.700\end{array}$ & $\begin{array}{r}54.400 \\
2.700 \\
31.000 \\
(2.400) \\
22.000 \\
1.100 \\
14.000 \\
50.500 \\
4.000 \\
43.000 \\
3.500 \\
118.900\end{array}$ \\
\hline $\begin{array}{l}21 \text { Passivo circulante (PĆ) } \\
211 \text { Empréstimos } \\
212 \text { Fornecedores } \\
213 \text { Salários } \\
214 \text { Impostos } \\
215 \text { Contribuiçōes } \\
216 \text { Dividendos } \\
22 \text { Exigivel a longo prazo (PELP) } \\
23 \text { Resultados de exercícios futuros (REF) } \\
24 \text { Patrimononio liquido \{PL) } \\
241 \text { Capital } \\
242 \text { Reservas } \\
243 \text { Lucros acumulados } \\
\text { Passivo total (PT) }\end{array}$ & $\begin{array}{r}15.100 \\
2.500 \\
7.000 \\
3.400 \\
1.500 \\
400 \\
300 \\
4.500 \\
100 \\
50.600 \\
23.000 \\
12.000 \\
15.600 \\
70.300\end{array}$ & $\begin{array}{r}17.900 \\
3.500 \\
8.000 \\
3.700 \\
1.700 \\
600 \\
400 \\
4.800 \\
200 \\
62.000 \\
25.000 \\
13.000 \\
24.000 \\
84.900\end{array}$ & $\begin{array}{r}19.700 \\
2.800 \\
10.000 \\
4.000 \\
1.800 \\
900 \\
200 \\
4.900 \\
100 \\
78.700 \\
28.000 \\
15.000 \\
35.700 \\
103.400\end{array}$ & $\begin{array}{r}18.800 \\
2.500 \\
8.000 \\
4.200 \\
2.300 \\
1.300 \\
500 \\
4.500 \\
300 \\
87.600 \\
31.000 \\
18.000 \\
38.600 \\
111.200\end{array}$ & $\begin{array}{r}22.200 \\
2.600 \\
11.000 \\
4.200 \\
2.300 \\
1.500 \\
600 \\
4.600 \\
250 \\
84.650 \\
32.000 \\
15.000 \\
37.650 \\
111.700\end{array}$ & $\begin{array}{r}25.700 \\
2.800 \\
14.000 \\
4.500 \\
2.500 \\
1.200 \\
700 \\
5.000 \\
350 \\
87.850 \\
32.000 \\
19.000 \\
36.850 \\
118.900\end{array}$ \\
\hline $\begin{array}{l}A C \\
A C \\
P C \\
C C L \\
A C C \\
P C C \\
10 G \\
A C F \\
P C O \\
T\end{array}$ & $\begin{array}{r}26.500 \\
15.100 \\
11.400 \\
26.800 \\
12.600 \\
14.200 \\
1.200 \\
4.000 \\
\{2.800)\end{array}$ & $\begin{array}{r}35.400 \\
17.900 \\
17.500 \\
35.100 \\
14.400 \\
20.700 \\
2.000 \\
5.200 \\
(3.200)\end{array}$ & $\begin{array}{r}45.500 \\
19.700 \\
25.800 \\
46.300 \\
16.900 \\
29.400 \\
1.800 \\
5.400 \\
(3.600)\end{array}$ & $\begin{array}{r}54.100 \\
18.800 \\
35.300 \\
54.500 \\
16.300 \\
38.200 \\
2.500 \\
5.400 \\
(2.900)\end{array}$ & $\begin{array}{r}51.700 \\
22.200 \\
29.500 \\
51.900 \\
19.600 \\
32.300 \\
2.900 \\
5.700 \\
(2.800)\end{array}$ & $\begin{array}{r}54.400 \\
25.700 \\
28.700 \\
54.100 \\
22.900 \\
31.200 \\
2.700 \\
5.200 \\
(2.500)\end{array}$ \\
\hline $\begin{array}{l}\text { Quocientes: } \\
\text { Liquidez corrente } \\
\text { Liquidez seca } \\
\text { Endividamenio total } \\
\text { Endividamento a curto prazo }\end{array}$ & $\begin{array}{l}1,03 \\
0,28 \\
0,77\end{array}$ & $\begin{array}{l}1,14 \\
0,27 \\
0,79\end{array}$ & $\begin{array}{l}2,31 \\
1,35 \\
0,24 \\
0,80\end{array}$ & $\begin{array}{l}2,88 \\
1,92 \\
0,21 \\
0,81\end{array}$ & $\begin{array}{l}2,33 \\
1,29 \\
0,24 \\
0,83\end{array}$ & $\begin{array}{l}2,12 \\
1,26 \\
0,26 \\
0,84\end{array}$ \\
\hline
\end{tabular}
cícios.

\section{Gráfico 1}

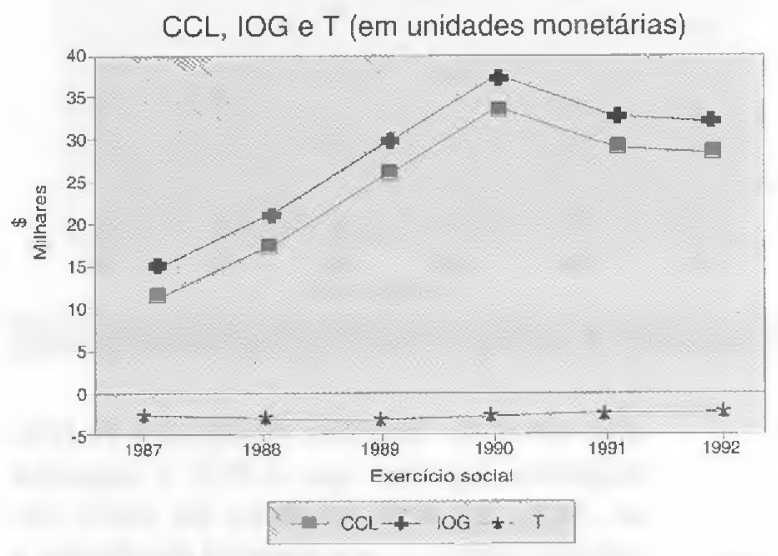

Todavia, a análise dos quocientes de liquidez e endividamento mais comuns exprimem resultados distintos. A partir do gráfico 2 percebe-se que os índices de liquidez corrente e seca sinalizam uma tendência de elevaçào nos primeiros quatro exercícios, e queda nos dois seguintes. Por 
outro lado, o endividamento total sinalizou tendência de declínio nos quatro anos iniciais, e elevação nos finais, ao passo que o endividamento de curto prazo indicou tendência contínua de alta. Em suma, a empresa transpareceu significativo nível de liquidez, endividou-se pouco em relação ao total do ativo, mas concentrou suas dívidas em itens de curto prazo. A avaliação do T, bastante diferente, antecedeu tais reversōes de tendência.

\section{Tipos de estruturas financeiras}

A combinação dos três elementos que compóem a posiçāo de curto prazo da organização ( $\mathrm{CCL}_{\ell} \mathrm{IOG}$ e $\mathrm{T}$ ) determina sua estrutura financeira em dado período além da tendência assumida para um horizonte de tempo mais dilatado - , assim como a situação de liquidez e solvência da entidade em igual momento - e sua evoluçāo no decorrer de exercícios sucessivos. Braga $^{7}$ identificou seis situaçōes possíveis pelo confronto daqueles elementos ${ }^{8}$, como mostra o quadro 8.

As companhias do Tipo I possuem uma situação financeira excelente em razāo do

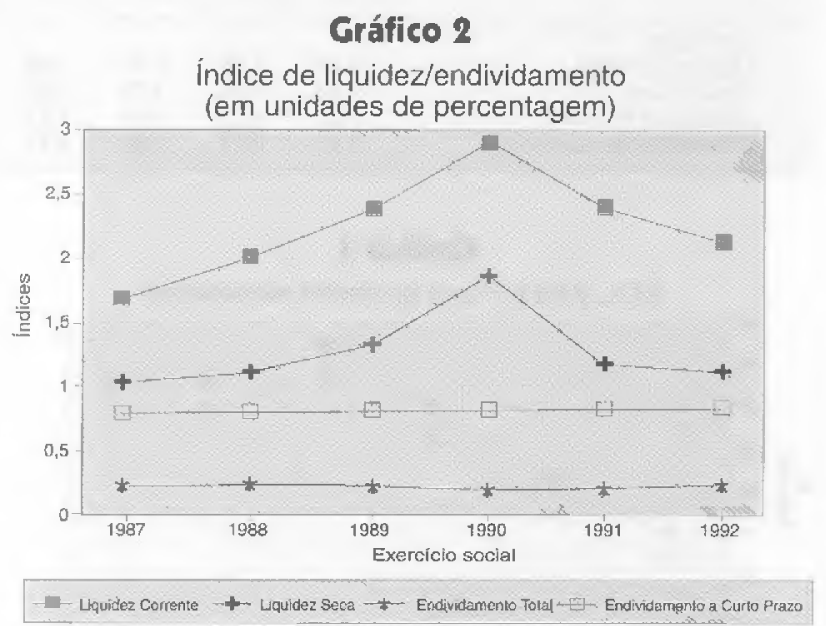

7. Em verdade Fleuriet citou apenas o caso do encargo da depreciação, quase sempre o provisionamento relativo mais relevante em termos de valor.

8. Como será comentado adiante, essa variação significa a alteraçāo verificåda no investimento operacional em Giro durante o exercício. alto nível de liquidez praticado. O IOG negativo significa que o PCC é superior ao $\mathrm{ACC}$, ou seja, os itens do ativo circulante cíclico - em especial duplicatas a receber e estoques - apresentam grau de rotaçăo elevados e, assim, ciclo financeiro reduzido. Embora seja superior ao montante do IOG, o CCL é inferior ao T, o que denota a existência de um ACF bem mais expressivo que o PCO. Essa configuração pode ser achada junto setor ao comercial varejista.

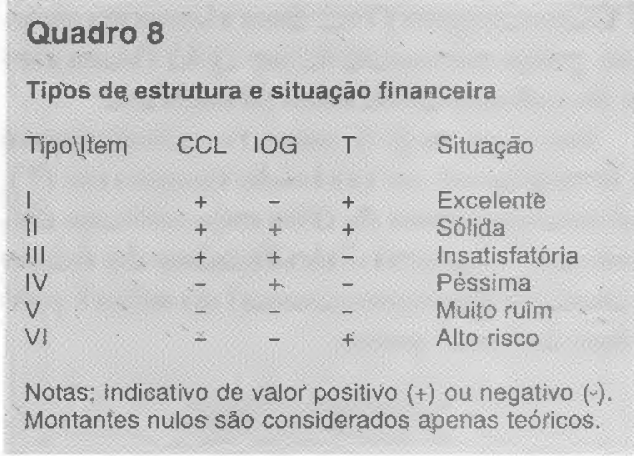

O Tipo II caracteriza uma firma com situação financeira sólida, e representa a posição mais usual encontrada no mundo real. O fato de os três elementos serem positivos faz com que o $\mathrm{T}$ no máximo se iguale ao IOG, mas seja sempre inferior ao CCL. Nesse sentido, os recursos de longo prazo investidos no CCL garantirăo a continuidade de um T favorável (positivo), desde que o nível de atividade operacional seja mantido. Caso esse nível sofra modificações - sazonalidade ou recessão, por exemplo -, podem surgir desequilibrios financeiros.

Os ramos de negócio que sustentam a estrutura do Tipo III evidenciam uma situação insatisfatória. T negativo significa que o CCL se acha insuficiente para garantir a manutenção do atual nível de atividade operacional, e que fontes de financiamento de curto prazo ( $\mathrm{PCO}$ ) vem sendo empregadas como complementares. Essa situaçăo pode agravar-se, por exemplo, na presença de recessão, ocasião em que itens do $\mathrm{ACC}$ encontrarăo dificuldades de realização (o ciclo financeiro aumenta), ao passo que o PCO tende a se elevar em função das taxas de juros significativas.

A situaçāo financeira péssima proveniente da adoção da estrutura do Tipo IV tem sido comum em certas companhias estatais, como as do ramo de geraçăo de energia elétrica e de transporte ferroviário. CCL negativo sinaliza que fontes de curto prazo financiam investimentos de longo prazo (ANC). Como há necessidades de capital de giro (IOG) e não se conta com CCL para seu financiamento, o passivo oneroso passa a cobrir essa insuficiência.

Na estrutura Tipo V a situaçāo financeira caracteriza-se como muito ruim. Além do CCL negativo, o que indica que fontes de curto prazo financiam ativos de 
longo prazo, o IOG também é negativo, sendo seu valor superior ao do primeiro.

Por fim, na situação de alto risco oriunda da utilização da estrutura do Tipo VI, permanecem negativos o CCL e o IOG, porém o valor deste é inferior ao do primeiro. Essa circunstância permite que o T seja positivo, e pode sinalizar para o fato de a empresa não estar desempenhando suas operações de maneira adequada, embora possa estar aplicando recursos de curto prazo (ACF) com eficiência no mercado financeiro.

\section{CONDICIONANTES DO INVESTIMENTO EM GIRO}

O IOG pode sofrer alteraçōes causadas tanto por mudanças no ciclo financeiro quer derivadas do emprego de políticas próprias, quer das condiçōes do ambiente - quanto pela variabilidade do volume de vendas do negócio, exibindo um grau de relacionamento direto a tais variáveis.

\section{Ciclo financeiro}

Existem ainda hoje dúvidas no que concerne aos conceitos de ciclo operacional, ciclo financeiro e ciclo econômico, assim como o modo pelo qual se relacionam. Numa empresa industrial, o ciclo operacional está ligado ao intervalo de tempo ocorxido entre a chegada de matérias-primas à fábrica e o momento do recebimento das duplicatas provenientes de vendas a prazo de produtos acabados.

Por sua vez, ciclo econômico significa o período de tempo decorrido entre a aquisiçāo de matérias-primas e a comercialização e entrega de produtos acabados, ou seja, a diferença temporal entre as transaçôes econômicas derivadas das compras e das vendas. Já o ciclo financeiro compreende o tempo decorrido entre o pagamento efetivo da compra de matérias-primas e o recebimento da venda de produtos acabados. Em outras palavras, está associado à variação de tempo entre os eventos financeiros da saída de disponível ocasionada pelo pagamento de duplicatas, $\mathrm{e}$ da entrada de disponível verificada pelo recebimento de duplicatas. $\mathrm{O}$ quadro seguinte esquematiza os três ciclos para um empreendimento industrial típico.

A partir do quadro 9 percebe-se a magnitude do ciclo econômico (CE) pela distância $\mathrm{CV}$ - período em que ocorrem as atividades produtivas de armazenagem,

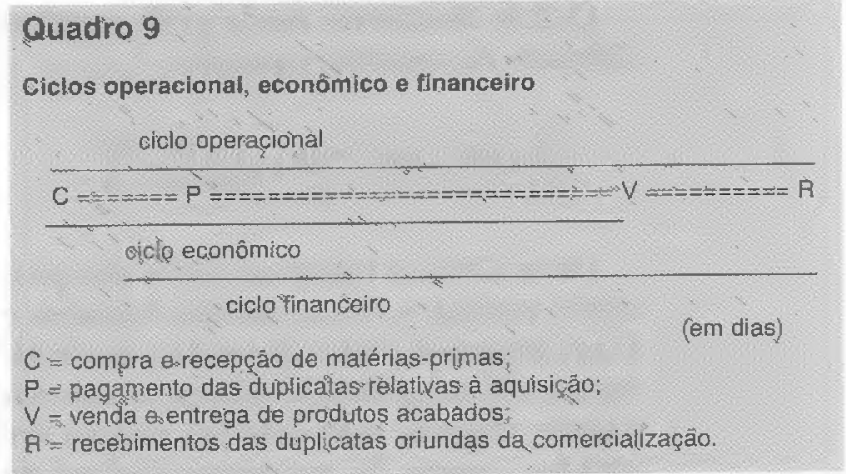

manuseio, movimentação, transformação e entrega - ao passo que o ciclo financeiro (CF) compreende o segmento PR. Já o ciclo operacional (CO) abrange todo o segmento CR. Todos podem ser também expressos em função dos prazos médios dos principais integrantes do IOG: duplicatas a receber (DR), estoques (E), e duplicatas a pagar (DP). Com base no quadro 5 notase que:

$$
\begin{aligned}
& C O=P M E+P M C \\
& C F=P M E+P M C-P M P \\
& C E=P M E \\
& P M E=P M M P+P M P P+P M P A
\end{aligned}
$$

Onde o PME acumula os prazos médios de estocagem das matérias-primas (PMMP), produtos em processo (PMPP), e produtos acabados (PMPA).

A extensão do ciclo financeiro varia de modo acentuado de acordo com o segmento industrial ou comercial no qual a companhia está inserida. Nesse sentido, o quadro 10 representa uma empresa industrial típica. O ramo de supermercados, por exemplo, evidencia uma configuraçáo bastante diversa, onde a quase totalidade das vendas sāo realizadas à vista, e as compras de mercadorias para revenda, a prazo. As margens de lucro desse setor podem ser reduzidas, dada a remuneraçáo obtida no mercado financeiro dos recursos provenientes do recebimento das vendas, os quais somente serão necessários $a$. posteriori, por ocasião do pagamento dos fornecedores. Pela notação adotada, verifica-se a seguinte condição usual para esse ramo de varejo:

$C V<C P$ ou $P M E<P M P$ e $P M R=0 \quad \log _{0} C F<0$ 
O ciclo financeiro ainda pode ser desdobrado na seguinte equação:

$$
C F=P M E+P M C-P M P=\frac{E}{C P V}+\frac{D R}{V L}-\frac{D P}{C}
$$

Onde CPV se refere ao custo dos produtos vendidos, VL às vendas líquidas, $\mathrm{e}$ Càs compras líquidas efetuadas. Normalmente tais componentes são expressos em valores médios, mas também podem ser obtidos a partir de montantes de final de exercício. Todavia, o IOG abrange outros ativos e passivos cíclicos de curto prazo (OAC e OPC, respectivamente), além dos já citados, quase sempre de menor importância relativa.

$$
I O G=D R+E-D P+(O A C-D P C)
$$

Ao dividir a equação pelo valor das vendas líquidas e em seguida multiplicá-la por 360 (fazendo uso de simplificaçōes algébricas), acha-se a medida IOG/vendas, expressa em dias, do mesmo modo que se evidencia a relação de proporcionalidade entre IOG e ciclo financeiro:

$$
\begin{aligned}
& \frac{1 O G}{V L}=\frac{D R}{V L}+\frac{E}{V L} \cdot \frac{C P V}{C P V}-\frac{D P}{V L} \cdot \frac{C}{C}+\frac{(O A C-O P C)}{V L} \\
& \frac{1 O G}{V L} \cdot 360=\left[\frac{D R}{V L}+\frac{E}{C P V} \cdot \frac{C P V}{V L}-\frac{D P}{C} \cdot \frac{C}{V L}+\frac{(O A C \cdot O P C)}{V L}\right] 360 \\
& 10 G \cdot 360=V L \cdot\left[P M C+P M E \cdot \frac{C P V}{V L}-P M P \cdot \frac{C}{V L}+\frac{(O A C-O P C)}{V L} \cdot 360\right] \\
& 10 G=V L \cdot P M C+C P V \cdot P M E-C \cdot P M P+360 \cdot(O A C-0 P C)
\end{aligned}
$$

Não obstante, deve-se ressaltar que o IOG deveria exprimir valores de final do exercício, o que faz com que o montante

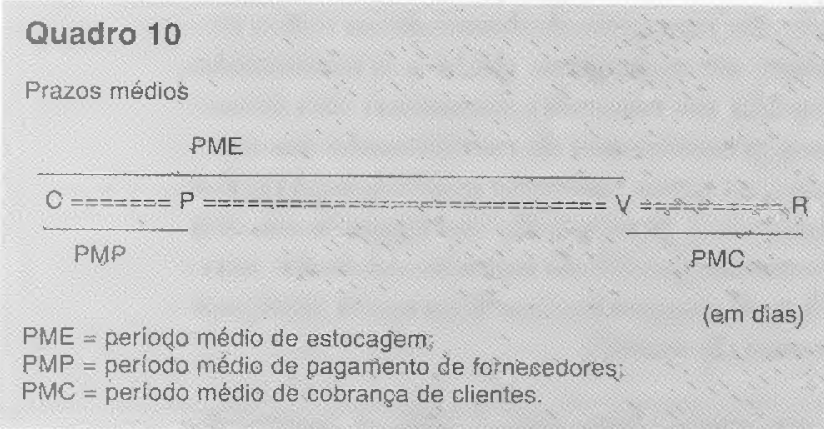

das vendas liquidas também esteja em unidades monetárias de igual data. Ou seja, esse item deve ser corrigido integralmente para moeda,de mesmo poder aquisitivo como meio de evitar distorções.

Ao considerar que a diferença líquida entre outros ativos e passivos cíclicos, positiva ou não, possui na maior parte dos casos pouca expressáo, a proporcionalidade entre IOG face ao $C F$ e às vendas fica ainda mais nítida.

\section{SAZONALIDADE DAS VENDAS}

O IOG também guarda uma relação direta com o nível e as variaçôes do volume de vendas, quer motivadas por sazonalidades do setor em que a empresa atua, quer por alterações no ambiente econômiCo - períodos de recessão ou crescimento. Os segmentos industriais de brinquedos e de adubos e fertilizantes são característicos de mudanças sazonais nas vendas em determinados meses a cada ano. As empresas de brinquedos possuem como ponto alto de vendas os meses de final de ano, próximos às festas natalinas. Nesse caso, os investimentos adicionais no IOG acontecem nos meses imediatamente anteriores àquele momento, ou seja, as firmas adquirem maiores quantidades de matérias-primas, e elevam o volume de duplicatas em carteira devido às vendas a prazo para clientes varejistas. Essa necessidade sazonal de capital normalmente acontece com acréscimos ao passivo circulante cíclico.

Já no ramo de adubos e fertilizantes, o período sazonal caracteriza-se por ser bem mais amplo, próximo a um semestre. As companhias desse setor investem em estoques de matérias-primas e produtos acabados usualmente no primeiro semestre de cada ano, para em seguida vender seus produtos, o que eleva o montante de duplicatas a receber. Como no caso anterior, essas inversões de recursos pressupōem financiamentos de curto prazo mais expressivos, como, dentre outros, salários e encargos a pagar, adiantamentos a fornecedores (fontes cíclicas), descontos de duplicatas, e empréstimos (tontes onerosas).

O segundo fator influenciador do IOG diz respeito às modificações no ciclo da economia. Em condições de crescimento, há uma relativa necessidade adicional por investimentos no IOG, que se manifesta 
sobretudo pelos aumentos nos saldos de duplicatas a receber e estoques. Esses acréscimos podem levar à contrataçāo de novos empréstimos de curto prazo (fontes onerosas), reduzindo o CCL, até que a empresa consiga outras fontes de financiamento de longo prazo que equilibrem o descompasso financeiro verificado. Caso isso não ocorra de forma adequada, o valor do saldo de tesouraria poderá se tornar negativo e assumir uma tendência crescente, o que ficou conhecido como efeito tesoura.

Por outro lado, nos períodos recessivos o desaquecimento das vendas provoca muitas vezes o encalhe dos estoques, bem como dificuldades no recebimento de duplicatas, motivadas por inadimplências de clientes. Esse IOG cm excesso foi em parte financiado por fontes onerosas de curto prazo, que, por sua vez, tendem a crescer em conformidade à elevação natural das taxas de juros. O CCl, permanece estável por algum tempo, e o 'l' tende a delcriorar-se ao longo do tempo, à medida que nāo sào gerados ativos circulantes financeiros pela realização daqueles ativos cíclicos.

A tabela 2 divulga os dados de uma empresa ao longo de seis exercícios sociais. A despeito de haver seguido a tendência visualizada para o CCL, em termos nominais o IOG foi superior àquele elemento nos dois períodos finais, o que propicia a existência de T' negativos nesses anos. $\mathrm{O}$ efeito tesoura ocorreu após 1990 (ver grálico 3). Fxistiu, assim, uma contínua deterioraçào financeira do negócio, fato comprovado pela queda sucessiva do índice T/VL.

Quando há o confronto entre a relação $\mathrm{T} / \mathrm{VL}$ e outros quocientes de liquidez e endividamento (ver gráfico 4), verifica-se a inexistência de indicativos precisos de insolvência nesses últimos.

\section{FINANCIAMENTO E AUTOFINANCIAMENTO 3) 106}

Num determinado instante, o investimento operacional em giro constitui-se de uma parcela fixa, necessária à manutençâo do atual nível de opcraçóes, e de outra variável, a qual se expande em ciclos sazonais ao longo de períodos específicos. $\Lambda$ parcela permanente deveria ser sustentada por fontes de financiamento também

\section{Tabela 2}

\begin{tabular}{|c|c|c|c|c|c|c|}
\hline digo/grupo & 1987 & 1988 & 1989 & 1990 & 1991 & 1992 \\
\hline $\begin{array}{l}11 \text { AC } \\
111 \text { Disponivel } \\
112 \text { Clientes } \\
113 \text { Duplicatas descontadas } \\
114 \text { Estoques } \\
115 \text { Despesas antecipadas } \\
12 \text { ARLP } \\
13 \text { AP } \\
131 \text { Investimento } \\
132 \text { Imobilizado } \\
133 \text { Diferido } \\
\text { AT }\end{array}$ & $\begin{array}{r}29.800 \\
4.200 \\
15.000 \\
(1.200) \\
11.000 \\
800 \\
8.000 \\
35.800 \\
2.000 \\
32.000 \\
1.800 \\
73.600 \\
\end{array}$ & $\begin{array}{r}39.000 \\
5.300 \\
19.000 \\
(1.400) \\
15.000 \\
1.100 \\
9.000 \\
40.500 \\
3.000 \\
35.000 \\
2.500 \\
88.500 \\
\end{array}$ & $\begin{array}{r}49.700 \\
5.300 \\
26.000 \\
11.900\rangle \\
19.000 \\
1.300 \\
10.000 \\
47.900 \\
3.000 \\
42.000 \\
2.900 \\
107.600 \\
\end{array}$ & $\begin{array}{r}57.400 \\
5.200 \\
35.000 \\
(2.300) \\
18.000 \\
1.500 \\
7.000 \\
50.100 \\
4.000 \\
43.000 \\
3.100 \\
114.500 \\
\end{array}$ & $\begin{array}{r}54.600 \\
5.400 \\
28.000 \\
(2.700) \\
23.000 \\
900 \\
9.000 \\
51.000 \\
8.000 \\
40.000 \\
3.000 \\
114.600 \\
\end{array}$ & $\begin{array}{r}57.100 \\
5.500 \\
31.000 \\
(2.500) \\
22.000 \\
1.100 \\
14.000 \\
50.500 \\
4.000 \\
43.000 \\
3.500 \\
121.600 \\
\end{array}$ \\
\hline $\begin{array}{l}21 \text { PC } \\
211 \text { Empréstimos } \\
212 \text { Fornecedores } \\
213 \text { Salários } \\
214 \text { Impostos } \\
215 \text { Contribuições } \\
216 \text { Dividendos } \\
22 \text { PELP } \\
23 \text { REF } \\
24 \text { PL } \\
241 \text { Capital } \\
242 \text { Reservas } \\
243 \text { Lucros acumulados } \\
\text { PT }\end{array}$ & $\begin{array}{r}14.700 \\
2.100 \\
7.000 \\
3.400 \\
1.500 \\
400 \\
300 \\
4.500 \\
100 \\
54.300 \\
23.000 \\
12.000 \\
19.300 \\
73.600\end{array}$ & $\begin{array}{r}17.600 \\
3.200 \\
8.000 \\
3.700 \\
1.700 \\
600 \\
400 \\
4.800 \\
200 \\
65.900 \\
25.000 \\
13.000 \\
27.900 \\
88.500\end{array}$ & $\begin{array}{r}19.700 \\
2.800 \\
10.000 \\
4.000 \\
1.800 \\
900 \\
200 \\
4.900 \\
100 \\
82.900 \\
28.000 \\
15.000 \\
39.900 \\
107.600\end{array}$ & $\begin{array}{r}19.000 \\
2.700 \\
8.000 \\
4.200 \\
2.300 \\
1.300 \\
500 \\
4.500 \\
300 \\
90.700 \\
31.000 \\
18.000 \\
41.700 \\
114.500\end{array}$ & $\begin{array}{r}22.500 \\
2.900 \\
11.000 \\
4.200 \\
2.300 \\
1.500 \\
600 \\
4.600 \\
250 \\
87.250 \\
32.000 \\
15.000 \\
40.250 \\
114.600\end{array}$ & $\begin{array}{r}26.200 \\
3.300 \\
14.000 \\
4.500 \\
2.500 \\
1.200 \\
700 \\
5.000 \\
350 \\
90.050 \\
32.000 \\
19.000 \\
39.050 \\
121.600\end{array}$ \\
\hline $\begin{array}{l}A C \\
P C \\
C C L \\
A C C \\
P C C \\
I O G \\
A C F \\
P C O \\
T\end{array}$ & $\begin{array}{r}29.800 \\
14.700 \\
15.100 \\
26.800 \\
12.600 \\
14.200 \\
4.200 \\
3.300 \\
900\end{array}$ & $\begin{array}{r}39.000 \\
17.600 \\
21.400 \\
35.100 \\
14.400 \\
20.700 \\
5.300 \\
4.600 \\
700\end{array}$ & $\begin{array}{r}49.700 \\
19.700 \\
30.000 \\
46.300 \\
16.900 \\
29.400 \\
5.300 \\
4.700 \\
600\end{array}$ & $\begin{array}{r}57.400 \\
19.000 \\
38.400 \\
54.500 \\
16.300 \\
38.200 \\
5.200 \\
5.000 \\
200\end{array}$ & $\begin{array}{r}54.600 \\
22.500 \\
32.100 \\
51.900 \\
19.600 \\
32.300 \\
5.400 \\
5.600 \\
(200)\end{array}$ & $\begin{array}{r}57.100 \\
26.200 \\
30.900 \\
54.100 \\
22.900 \\
31.200 \\
5.500 \\
5.800 \\
(300)\end{array}$ \\
\hline $\begin{array}{l}\text { Vendas liquidas } \\
\text { CGLNL } \\
\text { IOGNL } \\
\text { TNL }\end{array}$ & $\begin{array}{r}27.000 \\
0,56 \\
0,53 \\
0,03\end{array}$ & $\begin{array}{r}29.000 \\
0.74 \\
0.71 \\
0.02\end{array}$ & $\begin{array}{r}30.000 \\
1,00 \\
0,98 \\
0,02\end{array}$ & $\begin{array}{r}34.000 \\
1,13 \\
1,12 \\
0,01\end{array}$ & $\begin{array}{r}33.000 \\
0,97 \\
0.98 \\
(0,01)\end{array}$ & $\begin{array}{r}33.000 \\
0,94 \\
0,95 \\
(0,01)\end{array}$ \\
\hline $\begin{array}{l}\text { Quocientes: } \\
\text { Liquidez corrente } \\
\text { Liquidez seca } \\
\text { Endividamento total } \\
\text { Endividamento a curto prazo }\end{array}$ & $\begin{array}{l}2,03 \\
1,28 \\
0,26 \\
0,77\end{array}$ & $\begin{array}{l}2,22 \\
1,36 \\
0,25 \\
0,79\end{array}$ & $\begin{array}{l}2,52 \\
1,56 \\
0,23 \\
0,80\end{array}$ & $\begin{array}{l}2,07 \\
0,21 \\
0,81\end{array}$ & $\begin{array}{l}2,43 \\
1,40 \\
0.24 \\
0.83\end{array}$ & $\begin{array}{l}1.34 \\
0.26 \\
0.84\end{array}$ \\
\hline
\end{tabular}

\section{Gráfico 3}

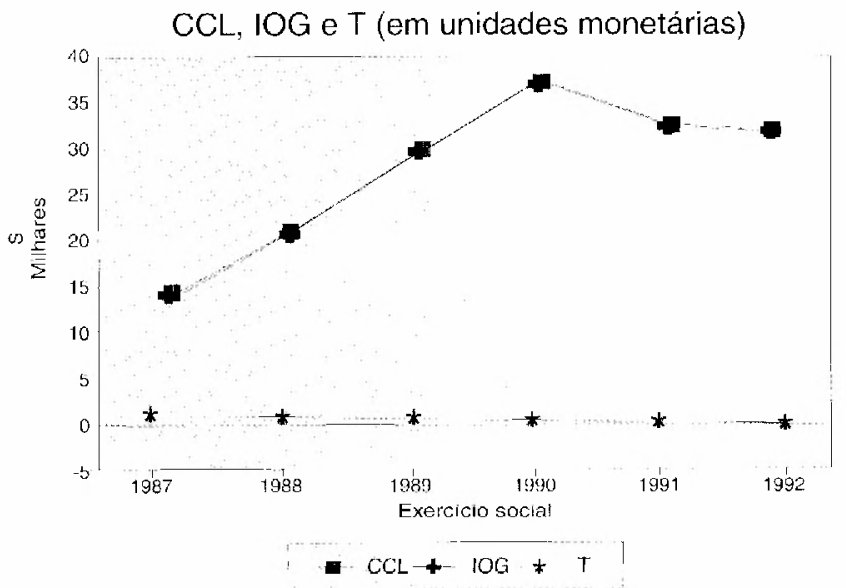




\section{ARTIGOS}

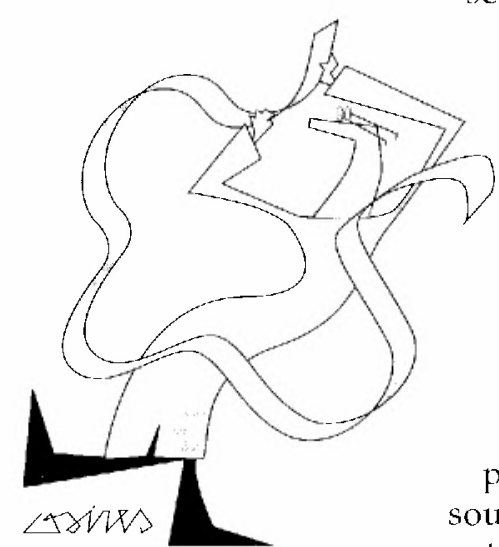
se apoiaria em recursos oriundos de obrigações onerosas de curto prazo. $\wedge$ medida que o negócio se desenvolve, tende a elevar-se de forma aproximadamente linear a parcela fixa relativa ao $\mathrm{IOG}$.

Com a continuidade da atividade, a cmpresa tende a se expandir de maneira a compatibilizar o crescimento do IOG sustentado por uma posição financeira sadia (CCL positivo e superior ao IOG), o que propicia a existência de saldos de tesouraria positivos e crescentes. Nesse contexto, o IOG necessita ser financiado de forma adequada por suas próprias atividades, ou seja, a geração de capital de giro das operaçóes, montante divulgado na demonstração das origens e aplicaçóes de recursos (DOAR) - quase sempre a principal origem de $\mathrm{CCl}$ disponivel às empresas - deduzida a fatia dos dividendos propostos. O valor resultante corresponde ao autofinanciamento (AUT) do empreendimento.

AUT $=$ Recursos gerados das operaçöes - Dividendos

\section{Gráfico 4}

Índice de liquidez/endividamento

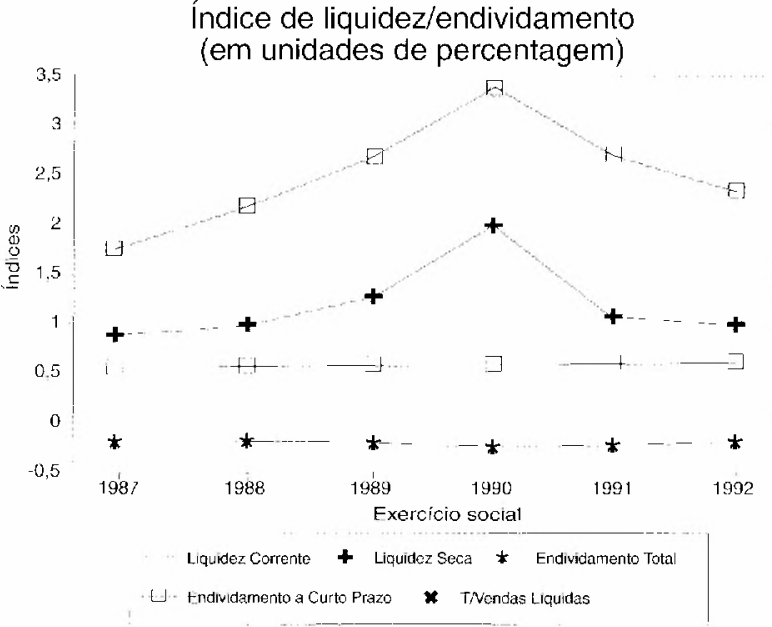

Na hipótese, por exemplo, de o IOG manter taxas de crescimento superiores àquelas achadas para o CCL num dado período, isso pode significar que as taxas de variaçāo do autofinanciamento estão estáveis ou decrescentes. Já que o montante dos recursos gerados das operações é calculado pela incorporação ao resultado líquido das receilas, custos e despesas que nāo afetaram o CCL durante o exercicio, pode não estar existindo renovação de ativos permanentes, o que tornaria a capacidade instalada obsoleta com o passar do tempo, além da possível inexpressividade dos lucros obtidos.

Pelo lado inverso, taxas de variação do IOG inferiores às do CCL poderiam ser indicio de elevado nível de autofinanciamento, o que denotaria uma possível recuperaçăo acentuada de capital investido cm ativos de longo prazo - via depreciação, amortização c exaustão - derivada de aplicaçócs maciças em bens e direitos (ativos) produtivos em exercícios anteriores, além da ocorrência de lucros satisfatórios.

Em linhas gerais, overtrading significa a realização de um nível de atividade operacional e volume de vendas acima da capacidade disponivel de recursos, ou seja, a administração expande os níveis de atividade e vendas do negócio sem o adequado suporte de recursos para ofinanciamento do capital de giro adicional requerido. $\Lambda$ razão mais comum para essa situação reside na busca por economias de escala no processo de produção, viabilizadas pela existência de capacidade ociosa na empresa.

O crescimento das operaçoes demanda maiores investimentos nos diversos segmentos de estoque e em duplicatas a pagar, enquanto o acréscimo ao volume de vendas pressupõc afrouxamentos da política de crédito desempenhada, clevando o montante de duplicatas a receber. $\mathrm{O}$ aumento líquido no $\mathrm{IOG}$ em grau superior ao do CCL força a empresa a procurar outras origens de recursos, em especial aquelas oriundas de passivos circulantes onerosos, conduzindo-à à situaçāo de overtrading.

A variação no nível geral de preços também pode levar a firma à situação de overtrading. À medida que o custo das matérias-primas aumenta nominalmente, bem como as expectativas de inflação são incorporadas ao valor das duplicatas, há necessidades adicionais de mobilização de recursos no IOG. Passivos cíclicos - como salários e encargos a pagar, adiantamen- 
tos a fornecedores, e impostos c contribuiçoes a recolher - sofrem do mesmo modo os efeitos da perda do poder aquisitivo da mocda, mas, em condições normais, relativamente menos que os ativos cíclicos, situaçăo que gera um acréscimo lícjuido ao $10 G$.

Conceito introduzido por Fleurict, o efeito tesoura inicia-se quando o saldo de tesouraria se torna negativo, c assume uma tendência crescente em termos absolutos a taxas maiores que aquelas verificadas para o IOG. Em outras palavras, T' elevase, visto que o CCL aumenta proporcionalmente mais que o $10 \mathrm{G}$. O desequilibrio motivado pelas necessidades emergentes de capital de giro não-sustentadas por autofinanciamentos é atendido mediante a contralaçăo de novos empréstimos bancários e o desconto de duplicatas da carteira possuida.

O efeito tesoura pode ser constatado a partir dos dados mostrados na tabela 3 . Embora tenha sinalizado tendência de piora da posição financeira ao longo dos seis anos, $\mathrm{T}$ somente passou a ser negativo após 1990. Ncsse exemplo, foram consideradas as seguintes situações: a. as vendas crescem $100 \%$ a cada período; b. o investimento no IOG corresponde a $50 \%$ das vendas; c. o CCL cresce a taxas de $70 \%$ ao ano; e d. o autofinanciamento a $80 \%$.

Enquanto a relação IOG/VI se estabilizou em 50\%, o quociente CCL/VL sinalizou tendência contínua de declínio, tornando-se inferior àqucla taxa a partir de 1990, e, assim, propiciou T/VL negativos após esse momento. Como a tendência do índice AUT/VL também foi de queda, parece que a empresa nāo vem gerando CCL satisfatório de suas operaçōes para financiamento do IOG. As vendas aumentaram, e com elas o IOG, mas isso não se traduziu num CCL maior. Outras razōes possíveis podem ser um acentuado grau de renovação de ativos produtivos de longo prazo e/ ou parcela expressiva das vendas a receber após o exercício seguinte.

O quadro 11 lista as companhias componentes da amostra. As empresas controladoras podem ser identificadas nos gráficos e tabclas pelas notações respectivas.

\begin{tabular}{|c|c|c|c|c|c|c|}
\hline Elomento & 1987 & 1988 & 1989 & 1990 & 1991 & 1992 \\
\hline Vendas líquidas (VL) & 3.000 & 6.000 & 12.000 & 24.000 & 48.000 & 96000 \\
\hline CCL & 2.200 & 3.740 & 6.358 & 10.809 & 18.375 & 31.237 \\
\hline $10 \mathrm{G}$ & 1.500 & 3.000 & 6.000 & 12.000 & 24.000 & 48.000 \\
\hline Autofinanciamento (AUT) & 1.200 & 2.160 & 3.888 & 6.998 & 12.597 & 22.675 \\
\hline $\mathrm{T}$ & 700 & 740 & 358 & $(1.191)$ & $(5.625)$ & $(16.763)$ \\
\hline Crescimento das VL & - & 1.00 & 1.00 & 1.00 & 1.00 & 1.00 \\
\hline CCLNL & 0.73 & 0.62 & 0.53 & 0.45 & 0.38 & 0.33 \\
\hline $10 \mathrm{G} / \mathrm{VL}$ & 0.50 & 0.50 & 0.50 & 0.50 & 0.50 & 0.50 \\
\hline AUT.NL & 0.40 & 0.36 & 0.32 & 0.29 & 0.26 & 0.24 \\
\hline $\mathrm{TNL}$ & 0.23 & 0.12 & 0.03 & $(0.05)$ & $(0.12)$ & $(0.17)$ \\
\hline
\end{tabular}

Notas: $10 \mathrm{G}=0.5$ das vendas líquidas

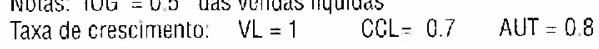

A tabela 4 apresenta os balanços reorganizados a partir dos demonstrativos financeiros sob correção integral publicados pelas empresas para o excrcicio findo em 31-12-1993. A seção inferior dessa tabela mostra os valores apurados para o CCL, IOG e T, assim como o gráfico 5 .

Os maiores IOG e $\mathrm{T}$ foram achados para a Ceval. Essa firma utilizou-se excessivamente de fontes onerosas de curto prazo (PCO) para o financiamento do $\mathrm{IOC}_{3}$, haja vista seu reduzido CCL disponível. Já a Sadia, a Avipal e a Frangosul divulgaram CCL superior ao IOG requerido, o que significa o emprego de saldos de tesouraria menos vultosos. A Frigobrás evidenciou CCL positivo, porém inferior às necessidades operacionais, empregando certo volume de recursos do PCO. Por fim, além de possuir o maior montante relativo de CCL negativo - recursos de curto prazo financiando ativos de longo prazo - , o T da Perdigão foi ainda mais alto. A despeito do reduzido IOG demandado por suas operaçoes, essa empresa recorreu de forma acentuada a fontes onerosas de curto praz,o, bem além de suas necessidades de capital de giro. Parece haver sinais de deterioração nos níveis relativos de solvência das firmas Perdigão e Ceval.

\section{Quadro 11}

Empresas integrantes e notações utilizadas

Ceval Alimentos S.A.

Perdigão Agro-Industrial S.A. Ceval Frangosul S.A. Agro-Avicola Industrial Frangosul Frigobrás Cia. Brasileira de Frigoríficos Frigobrás Sadia Concórdia S.A. Indústria e Comércio Sadia Avipal S.A. Avicultura e Agropecuária Avipal 
hitata 4

\begin{tabular}{|c|c|c|c|c|c|c|}
\hline Conta/cia. & Ceval & Perdigāo & Frangosul & Frigourâss & Sadia & Avipal \\
\hline ATNO CIRCILLANTE & 116.440 & 27.463 & 9.475 & $38.42 b$ & 97.630 & 28.560 \\
\hline Caixatbancos & 807 & 596 & 140 & 110 & 655 & 99 \\
\hline Apticaçoes financeiras & 36.644 & & 1.447 & 5 & 0 & 996 \\
\hline Outras disponibilidades & & - & & & & \\
\hline Clientes nacionais & 10.654 & 8510 & 3681 & 8.656 & 20838 & 3.500 \\
\hline Clientes externos & & - & & & & \\
\hline Adiantamentos a fomecedores & 1220 & - & 58 & - & - & - \\
\hline Provisão p/devedores duvidosus & (71) & - & (31) & $(100)$ & (339) & $(52)$ \\
\hline Valores descontados & & - & & $(1375)$ & $(4.066)$ & \\
\hline Impostos recuperados & 3.534 & - & 18 & 79 & 1.133 & $25 ?$ \\
\hline Títilos e valores mohiliários & & - & $\hat{3}$ & 33 & 28.098 & 6.894 \\
\hline Partes ligadas & - & - & - & - & - & 7.059 \\
\hline Estoques & 44.789 & 16.198 & 3.994 & 28.817 & 48.220 & 9.559 \\
\hline Despesas do exercício seguinte & 1.028 & 2.159 & 2 & 1.427 & 68 & 75 \\
\hline Outros valores & 17.834 & & 164 & 774 & 2923 & $1 / 9$ \\
\hline REAL IZAVII A I ONGO PRA7O & $317 ?$ & $5 ? 686$ & 65 & 3.677 & 5450 & 5939 \\
\hline Partes ligadas & 424 & 34.474 & 0 & 2565 & 1.114 & 2722 \\
\hline \multirow{3}{*}{$\begin{array}{l}\text { Depósitos judiciais/outros } \\
\text { Depositos compulsóriosi } \\
\text { ELETROBRAS }\end{array}$} & 1.620 & 18.117 & & & 3.473 & \\
\hline & - & - & 58 & 398 & 829 & 3.217 \\
\hline & 128 & 95 & 7 & 114 & 33 & 0 \\
\hline ATIVO PERMANENTE & 192.743 & 91787 & 36125 & 37.281 & 99.300 & 47605 \\
\hline Sociedades ligadas & 53.632 & 5183 & 5641 & $490 ?$ & 44.625 & 10280 \\
\hline Incentivos tiscais'outros & 1.050 & 270 & & & & 64 \\
\hline Imobilizado & 179.429 & 149.343 & 38.722 & 56.433 & 106.099 & 49.373 \\
\hline Depreciação acumulada & $\begin{array}{r}(18.674) \\
0.280\end{array}$ & $\{63.065\rfloor$ & $(8.238)$ & $(25303)$ & $(51.900)$ & (12.111) \\
\hline $\begin{array}{l}\text { Diferido } \\
\text { Amortizaçāo acumulada }\end{array}$ & $\begin{array}{r}9.280 \\
(1.9 / 4)\end{array}$ & 56 & - & 1.250 & 476 & \\
\hline$A \mathbf{T}$ & 312.355 & 171936 & 45,665 & 79384 & 202280 & 82.104 \\
\hline PASSIVD CIRCULANTE & 131.855 & 66.115 & 3.995 & 27.404 & 51.555 & 8.206 \\
\hline Instituiçoes financeiras & 112.887 & 26.513 & 560 & 5.017 & 17.308 & 1.572 \\
\hline Fornecedores & 4.485 & 12.398 & 1.337 & 3.300 & 6.339 & 1.057 \\
\hline Adiantamentos do câmbio & & 14.197 & & & & 36 \\
\hline Adianlamenlus de clientes & 6742 & 684 & 4 & 13.631 & 12.289 & 76 \\
\hline $\begin{array}{l}\text { Partes ligadas } \\
\text { Sajários/encargos sociais }\end{array}$ & & & & & & \\
\hline $\begin{array}{l}\text { Sajârios/encargos sociais } \\
\text { Provisão para IR/cont. sind. }\end{array}$ & 1.799 & 4.530 & 1.628 & 574 & 1.705 & 711 \\
\hline Imposto lucro líquido & - & - & 202 & - & - & 76 \\
\hline Tributário & 3.310 & 2.619 & 160 & 1.446 & 5.496 & 419 \\
\hline $\begin{array}{l}\text { Dividendos/participaça de } \\
\text { adminislradores }\end{array}$ & 1.321 & & 0 & 827 & $177^{2}$ & 4236 \\
\hline Debêntules & & 620 & & & & \\
\hline Contas/outros valores & 1.310 & 4.354 & 104 & 2609 & 6645 & 23 \\
\hline FXIGIVEL A LONGO PRAZO & 30.315 & 21.315 & 6.640 & 8.717 & 41.368 & 2.306 \\
\hline \multicolumn{7}{|c|}{ RESUL1ADOS DE EXERCICIOS FUTUROS } \\
\hline PATRIMOCNIO LIQUHDO & 150.186 & 84506 & 35030 & 43.262 & 109357 & 71.592 \\
\hline Capital atualizado & 96.000 & 93.016 & 19.540 & 25.044 & 53.653 & 27.546 \\
\hline Reservas & 54.186 & 234 & 15.053 & 8.764 & 21.360 & 8.174 \\
\hline Lucros (Prejuizo) acumulados & & $(8.744)$ & 437 & 9.455 & 34.344 & 35.872 \\
\hline PASSIVO TOTAL & 312.355 & 171.936 & 45.665 & 79.384 & 202.280 & 82.104 \\
\hline $\mathrm{AC}$ & 116.440 & 27.463 & 9.475 & 38.425 & 97530 & 28.560 \\
\hline $\mathrm{PC}$ & 131.855 & 66.115 & 3.995 & 27.404 & 51.555 & 8206 \\
\hline $\mathrm{CCL}$ & $(15.414)$ & $(38.652)$ & 5.480 & 11.021 & 45975 & 20354 \\
\hline$A C C$ & 78.989 & 26.867 & 7.885 & 39.653 & 72.843 & 13.513 \\
\hline PCC & 17.646 & 24.785 & 3.233 & 21.560 & 32,475 & 2285 \\
\hline $10 G$ & 61343 & 2082 & 4652 & 18092 & 40368 & 11.227 \\
\hline ACF & 37.451 & 596 & 1.590 & 148 & 28.753 & 15.048 \\
\hline $\mathrm{PCO}$ & 114208 & 41.330 & 762 & 7.219 & 23.146 & 5.921 \\
\hline I & $(76.757)$ & $(40.734)$ & 828 & $(7.071)$ & 5607 & 9.127 \\
\hline
\end{tabular}

Gráfico 5

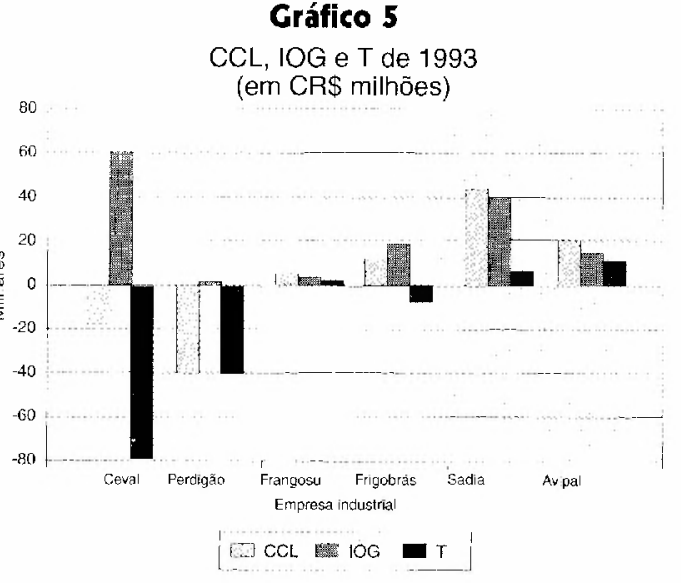

Utilizar saldos de tesouraria jamais significará má gestão financeira. Existe a necessidade de fontes onerosas de recursos para investimento na atividade operacional do empreendimento, inclusive para atender necessidades sazonais de capital. Todavia, o problema surge quando da exposição de $\mathrm{T}$ crescentes ao longo de um certo número de anos.

A tabela 5 expõe as demonstrações de resultado reorganizadas, e os montantes respectivos do lucro bruto operacional. Os valores encontrados foram positivos (lucro), embora uma companhia tenha cvidenciado prejuízo líquido contábil: a Perdigâo.

O fluxo de caixa operacional" acha-se disposto na tabela 6. O FCO apcnas não foi positivo para a Ceval. Em princípio, parece que a empresa clevou substancialmente seu nivel de investimento nas operaçóes durante o ano de 1993, molivo que a teria levado a consumir acentuado caixa nessa atividade, já que seu LBO foi insuficiente para sustentá-lo. Por seu turno, a Perdigão reduziu de um ano a outro seu nível de operações, o que elevou seu FCO.

Em princípio, quanto menor a variação do IOG ao longo do tempo, mais estável seria a entidade. Nesse aspecto, a companhia mais estável aparentemente foi a Frangosul, muito embora haja relatado ligeira queda $\mathrm{cm}$ suas operações.

Por fim, a tabela 7 e o gráfico 6 expõem as diferenças relativas de determinadas medidas de desempenho. Enquanto a Avipal foi a que mais demandou investimentos no IOG $\mathrm{cm}$ relação à suas vendas liquidas (ROL), a Perdigăo foi a que menos investiu. A Avipal foi também a firma de maior margem sobre as operaçóes (LBO/ROL), e a Sadia a de menor margem.

Ambos os modos de divulgação de resultados mostram o relacionamento entre rentabilidade e liquidez para esse reduzido número de empresas. O nível de liquidez (FCO/Ativo Bruto) se distanciou mais da taxa de retorno contábil (Retorno Ativo Total) para a Perdigão, a Frangosul e a Avipal, e da taxa de retorno operacional (Retorno Ativo Operacional) nos demais casos. A Avipal evidenciou o maior grau de retorno total, $\mathrm{c}$ a segunda menor relação indicativa da liquidez. Por outro lado, 


\section{Gráfico 6}

Rentabilidade e Liquidez de 1993 (em unidades percentuais)

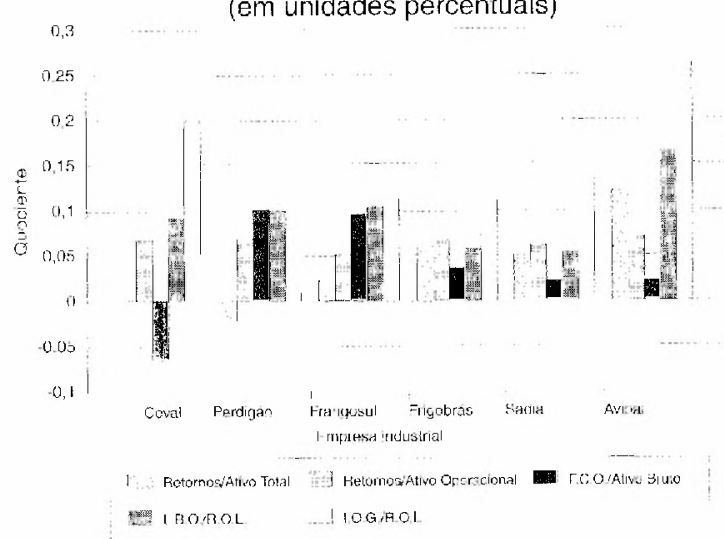

a Perdigão demonstrou a maior relação de liquide $z$, mas o retorno total mais baixo (inclusive negativo).

Seria dificil estabelecer algum grau de relacionamento entre esses quocientes com base numa amostra tão pequena. Ainda assim, a metodologia descrila poderia viabilizar essa medição.

\section{CHOCISAT}

O modelo descrito neste estudo auxilia o analista financciro na avaliação da liquidez e solvência da entidade, e na identificação do tipo de estrutura financeira utilizada e/ou característica do segmento de interesse, bem como a verificação de suas tendências relativas.

Nesse aspecto, serve de instrumento suplementar à análise de liquidez tradicional, às vezes fornecendo indicativos antecipados de deterioração ou recuperação financeira da empresa. O montante do fluxo de caixa operacional significa, em verdade, uma medida aproximada do item caixa gerado das atividades operacionais, divulgado na demonstraçāo de fluxos de caixa. Contudo, no Brasil esse demonstrativo ainda não foi solicitado pelos órgãos legais para fins de evidenciação.

Os resultados obtidos permitiram uma comparaçāo da magnitude do investimento operacional em giro mantido pelas empresas para a implementação do nível desejado de operaçóes, e o grau de endividamento (saldo de tesouraria) praticado. $\mathrm{O}$ relacionamento entre níveis de retorno e liquidez também foi verificado

\section{Tabela 5}

\begin{tabular}{|c|c|c|c|c|c|c|}
\hline liem & Ceval & Perdigão & Frangosul & Frigobrás & Sadla & Avipa! \\
\hline Receita operaciontal brua & 335.183 & 171.026 & 42.986 & 167800 & 324.426 & 44.990 \\
\hline Débucües & $(30.148)$ & $(17.781)$ & (3.471) & $(19.755)$ & $(36.649)$ & $(3.110)$ \\
\hline Receita operacionat líquida & 305.035 & 153.245 & 39.515 & 148.046 & 287.777 & 41.880 \\
\hline Custo das vendas & $(24 / .845)$ & $(113250)$ & $(29391)$ & $(111.742)$ & (227.681) & (31.233) \\
\hline Lucio operacional bruto & 57.191 & 39.995 & 10.124 & 36.303 & 60.096 & 10646 \\
\hline Despesas operacionais & $(38.708)$ & $(30.005)$ & $(8.056)$ & $(30622)$ & $(51.312)$ & (6.646) \\
\hline Corn vendas & $(28.111)$ & $(24403)$ & $(5484)$ & $(21.460)$ & $(35.696)$ & $(3.432)$ \\
\hline \multicolumn{7}{|l|}{ Geraisiadministrativas: } \\
\hline honorários & $(8.246)$ & $(5630)$ & $(2.5 / 2)$ & $(10.198)$ & $(17.919)$ & $(1.179)$ \\
\hline Outtas receitas operacionais & & 28 & & 1.490 & 4.152 & 117 \\
\hline Outras despesas operacionais & $(2.350)$ & & & (454) & $(1949)$ & $(2.152)$ \\
\hline Resulteifu uperacionat & 18.483 & 9990 & 2.068 & 5681 & 8.784 & 4000 \\
\hline Resultado nāo-operacional & $(16805)$ & $(13.816)$ & $(983)$ & $(121)$ & 1.477 & 6.271 \\
\hline $\begin{array}{l}\text { Hesultado ded equivaléncla } \\
\text { Wadrimmonial }\end{array}$ & & 123 & & $(870)$ & 5.044 & 6067 \\
\hline $\begin{array}{l}\text { Walrummial } \\
\text { Hecetas financeiras }\end{array}$ & $\begin{array}{r}14.087 \\
1.332\end{array}$ & 120 & 190 & 3913 & 4.598 & 1.401 \\
\hline Despesas financeiras & $(30471)$ & $(12.880)$ & $(1.349)$ & $(3587)$ & $(12.488)$ & (217) \\
\hline Outras receitas & - & & 17 & 423 & 4.273 & 53 \\
\hline Outras despesas & $\{2,662\}$ & $(1.058)$ & & . & - & (116) \\
\hline P. R/cont tibuição social & . & 0 & $(129)$ & - & - & $(917)$ \\
\hline Participaçäo dos adninis radores & - & - & - & - & - & \\
\hline Oulras participaçōes;provisoes & & - & & - & & \\
\hline Resultado líquido & 1.678 & $\langle 3825\rangle$ & 1.085 & 5.560 & 10210 & 10.271 \\
\hline Resutado operacional & 18483 & 9.990 & 2.068 & 5.681 & 8784 & 4.000 \\
\hline Depreciação/anı tizaçãolexaustáo & 09.167 & 5428 & 2.374 & 3.771 & 7.824 & 3.265 \\
\hline $\begin{array}{l}\text { I.BO } \\
\text { I. }\end{array}$ & 27650 & 15.418 & 4.443 & 9.452 & 16.608 & 7.265 \\
\hline
\end{tabular}

\section{Tabela 6}

Fluxo de caixa operacional

\begin{tabular}{|c|c|c|c|c|c|c|}
\hline LEO & 27.650 & 15.418 & 4.443 & 9.452 & 16.608 & 7.265 \\
\hline IOG final & 61.343 & 2.082 & 4.652 & $18.09 ?$ & 40.368 & 11.227 \\
\hline $10 \mathrm{G}$ inicial & 10.162 & 12.516 & 5.347 & 12.087 & 29.289 & 5.903 \\
\hline Variaçàa & 51.181 & $(10.434)$ & (695) & 6.005 & 11.079 & 5.324 \\
\hline $\mathrm{FCO}$ & (23 531) & 25.852 & 5.138 & 3.447 & 5.529 & 1.941 \\
\hline
\end{tabular}

\section{Tabela 7}

Índices financeiros e quocientes de fluxo de caixa

\begin{tabular}{|c|c|c|c|c|c|c|}
\hline IOG/ROL & $20,11 \%$ & $+36 \%$ & $11.77 \%$ & $12.22 \%$ & $14,03 \%$ & $26,81 \%$ \\
\hline LBO/ROL & $9,06 \%$ & $10.06 \%$ & $11,24 \%$ & $6.38 \%$ & $5.77 \%$ & $17,35 \%$ \\
\hline Ativo operacional & 256121 & 131.914 & 40.014 & 71.170 & 128.409 & 55,086 \\
\hline Atlvo total bruto & 363.003 & 235.001 & 53.903 & 104.687 & 254.180 & 94215 \\
\hline Retorno s/ativo operacional & $7,22 \%$ & $7,57 \%$ & $5.17 \%$ & $7.98 \%$ & $6,84 \%$ & $7,26^{\mathrm{v} /}$ \\
\hline Retorne siativo total & $0,54 \%$ & $-2,22 \%$ & $2,38 \%$ & $7,00 \%$ & $5,05 \%$ & $12,51 \%$ \\
\hline FCorativo aruto & $-6,48 \%$ & $11,00 \%$ & $9.53 \%$ & $3,29 \%$ & $2.16 \%$ & $2,06 \%$ \\
\hline
\end{tabular}

para essa reduzida amostra. Não foi identificada, cntretanto, a tendência desses elementos, o que somente seria possivel com o emprego de um horizonte de tempo mais dilatado.

Esse campo de pesquisa permanece ainda pouco explorado. Outros estudos poderiam adotar amostras mais significativas e definir tendências setoriais específicas. Há sinais de que essa árca receberá contribuições relevantes nos próximos anos, em especial dada a busca por medidas mais eficientes na avaliação da liquidez em ambientes econômicos cada vez mais globalizados.

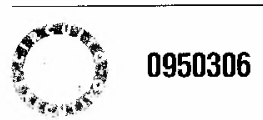

11. Denominação utilizada no estudo original de Fleuriet. Siva empregou o primeiro termo, sendo depois seguido por outros autores.

12. BRAGA, Roberto. Análise avançada do capital de giro. Op. cit., p. 17-21.

13. 0 estudo original de Fleuriet citou quatro tipos de estrutura financeira, mas apontou para a existência de outras duas possibilidades. Braga descreveu as seis formas de estrutura.

14. Os valores foram calculados pela diferença entre os $10 G$ S final e inicial respectivos, esse último corrigido para moeda de 31-12-1993. 